\title{
Utilization of Waste Papers to Produce Ecofriendly Bricks
}

\author{
Rohit Kumar Arya ${ }^{1}$, Rajeev Kansal ${ }^{2}$ \\ ${ }^{1}$ PG Student, Construction Technology \& Management, Madhav Institute of Technology and Science, Gwalior, Madhya Pradesh, India \\ ${ }^{2}$ Professor of the Civil Engineering Department, Madhav Institute of Technology and Science, Gwalior, Madhya Pradesh, India
}

\begin{abstract}
A new nature study estimates the world has 3.04 trillion trees. Almost 4 billion trees worldwide iscut down each year for making paper. The construction industry has been known as one of the largest consumers of non-renewable resources. On the other hand, more waste paper ends up in landfill or dump sites than those recycled. The purpose of this research is to determine the weight, compressive strength, water absorption capacity, fire resistance, hardness etc of papercrete brick by using waste papers (newspapers, invitation cards, magazines etc.) in order to determine their aptness for use as a building construction material. While using paper pulp with cement and sand the weight of the brick is approximately $50 \%$ lesser than the conventional clay brick. Therefore papercrete bricks will decrease the dead weight of the structure to a significant amount. So it changes our design and building cost as in an economical point of view.
\end{abstract}

Keywords: Papercrete, Cellulose, Light Weight, Compressive strength, Recycling

\section{Introduction}

According to a research, more than 450 million tons of papers are produced worldwide every year. It is estimated that by 2020, paper mills will be producing 500 million tons of paper and paperboard each year. We obviously need this product and a reduction of use is not in the prospect. Pulp and paper is the $3^{\text {rd }}$ largest industrial polluter of air, water and soil. In recent year, paper and paperboard constitute a greater portion of many countries's municipal solid waste generation.

According to the Environment Protection Agency (EPA), the Unites States recycles about $45 \%$ of discarded paper annually. This means that about $55 \%$ or 48 million tons of paper ends up in landfill sites while some are incinerated. Waste paper reusing has not been able to match waste paper generation.

Since the large demand has been placed on the construction industry, especially in the last decade due to increase in pollution which cause a chronic shortage of building resources, the civil engineers have been challenged to convert the industrial waste to useful building and construction materials. One exclusive recycle opportunity is using waste paper as a construction material. Since the construction industry uses up a great amount of nonrenewable resources, therefore the potential function of waste paper for producing a low cost and light weight composite brick for construction not only delivers the potential use of waste paper recycling but it will likewise bring down the demand pressure on global natural resources.

In recent years, there has been a renaissance of interest in traditional building material, particularly those made from renewable or recycled materials "papercrete" is one of such materials attracting public interest.

Papercrete is a complex material comprising of Portland cement, waste paper, water and/or sand. The combination of these materials, which may provide a way to provide affordable housing on a large scale.

Papercrete have been reported: to be cheap alternative building material; to have good sound absorption and thermal insulation; to be a light weighted and fire- resistant material(Annesly 2014; Fuller 2014; Nepal \& Aggarwal 2014; Santamaria et al. 2007; Solberg 1999).

Although it is originally developed 80 yearsago, but it has only recently been rediscovered and only few research works have been done to determine their structural suitability (Fuller at el. 2006).

It should be noted that papercrete is a comparatively new concept with limited scope. Papercrete is known by alternative names such as fibrous concrete, Padobe and Fidobe.

Fibrous concrete is a mixture of paper, Portland cement and water. There is no harmful byproducts or excessive energy use in the production of papercrete. Padobe has no Portland cement. Here, instead of Portland cement, clay is the binding material. It is a mix of paper, water and earth with clay. Fidobe is like Padobe, but it may possibly contain other fibrous material.

\subsection{Project Viewpoint}

The purpose of present research is to utilize the waste materials like paper and to replace the costly and rare conventional building brick which satisfies the following characteristics:

- Required

- Cost effective

- Environmental friendly

- Less weight

- Inflammable

- Easily available 


\section{International Journal of Science and Research (IJSR) \\ ISSN (Online): 2319-7064}

Index Copernicus Value (2013): 6.14 | Impact Factor (2015): 6.391

In order to achieve the above mentioned, objective study work has been divided into three main parts:

1. Accumulation of material

2. Experimental procedure

3. Results and discussions

\subsection{Accumulation of Material}

Material collection is the basic and important step in any project. Also, the material which is used in a project should not cause any damage to the environment. In this research, waste materials were used to make building bricks.

\subsubsection{Cement}

Cement is one of the binding material in this research. Cement is the important binding material in today's construction world 53 grade Ordinary Portland Cement (OPC) confirming to IS: 8112-1989 cement used.Table 1.1 gives the properties of cement used.

Table 1.1.1: Properties of cement

\begin{tabular}{|l|c|c|}
\hline \multicolumn{1}{|c|}{ Description of test } & $\begin{array}{c}\text { Results } \\
\text { obtained }\end{array}$ & $\begin{array}{c}\text { Requirement of } \\
\text { IS: } 8112-1989\end{array}$ \\
\hline 1. Specific gravity & 3.15 & 3.15 \\
\hline 2. Initial setting time & 75 minutes & Min. 30 minutes \\
\hline 3. Final setting time & 270 minutes & Max. 600 minutes \\
\hline 4. Fineness & $412.92 \mathrm{~m}^{2} / \mathrm{kg}$ & Min. $225 \mathrm{~m}^{2} / \mathrm{kg}$ \\
\hline
\end{tabular}

\subsubsection{Sand}

Sand particles consist of small grains of silica $\left(\mathrm{SiO}_{2}\right)$. It is formed by the decay of sand stones due to various effects of weather. According to natural resources from which the sand is obtained, it is termed as pit sand, river sand and sea sand. According to the size of grains, the sand is classified as fine, coarse and gravel.The properties were analyzed as per BIS standard.

Table 1.2.1: Properties of Sand

\begin{tabular}{|c|c|c|}
\hline Sr. No. & Properties & Results obtained \\
\hline 1 & Fineness & $4.40 \%$ \\
\hline 2 & Specific gravity & 2.60 \\
\hline
\end{tabular}

\subsection{Paper}

Paper is a natural polymer which consists of wood cellulose. Cellulose is made of units of monomer glucose. Although containing several hydroxyl groups, cellulose is water insoluble. The reason is the stiffness of the chain and hydrogen bonding between two $\mathrm{OH}$ groups on adjacent chains. The chains also pack regularly in places to form hard, stable crystalline region that gives the bundle chains even more stability and strength.

Fig 1.3.1 shows the links of cellulose bonds.

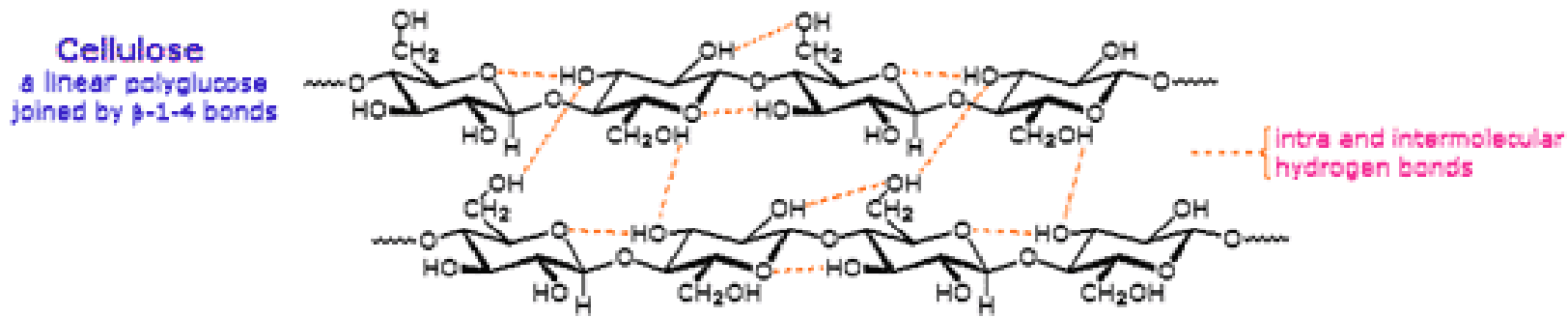

Figure 1.3.1: Cellulose hydrogen bond

The above figure shows the network of cellulose fibers and smaller offshoots from the fibers called fibrils. Coating this fiber with Portland cement creates a cement matrix, which encases the fibers for extra strength.

Different type of papers like newspaper, magazines, old invitation cards, paper tickets etc can be used for making papercrete. The papers, which were collected, cannot be used directly. It should be made into paper pulp before mixing with other ingredients.

\subsection{Water}

Water is an important ingredient of papercrete as it is involved in the chemical reaction with cement. Potable water should be used for both soaking and mixing of papercrete. It should be free from organic matter and the $\mathrm{pH}$ value should be between 6 and 7 .

\subsection{Papercrete Additives}

Cement is added to the matrix as a binding material. In addition to that, waterproofing admixtures such as Dr. Fixit
$101 \mathrm{LW}^{+}$is added to the mix for minimizing the percentage of water.

\section{Experimental Procedure}

According to research, up to now, there is no hard and fast rule for formal mix design of papercrete, and in that respect no hard procedure for casting the bricks. Thus, in this research, some laboratory tests were performed to obtain some mechanical properties of papercrete.

\subsection{Mould Preparation}

After collecting all the materials, a mould was prepared. A wooden modular brick mould was prepared of size $230 \mathrm{~mm}$ X $110 \mathrm{~mm}$ X $80 \mathrm{~mm}$. Joints were made without any hole or gap to avoid any leakage.

\subsection{Pulp Generation}

The papers, which were collected, cannot be utilized immediately. It should be made into apaper pulp before mixing with other ingredients. The papers were kept in the 


\section{International Journal of Science and Research (IJSR) \\ ISSN (Online): 2319-7064 \\ Index Copernicus Value (2013): 6.14 | Impact Factor (2015): 6.391}

tank for 3 to 4 days, otherwise until the papers degrade into a paste-likeform. Then the paper was taken out of the water and taken to the mixer machine to make it as a paper pulp.

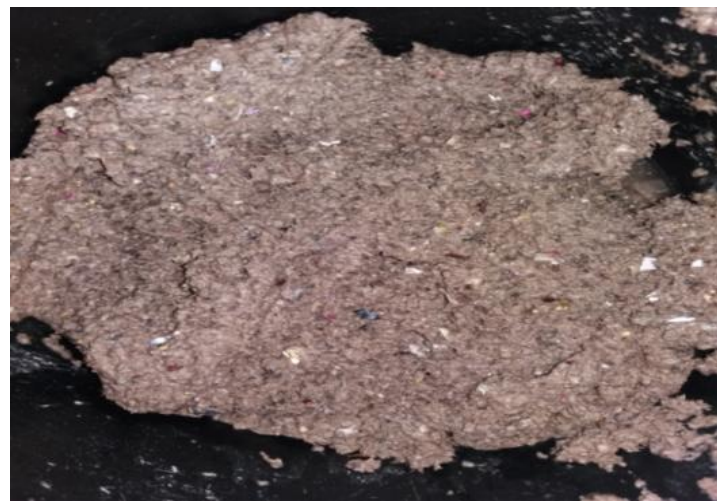

Figure 2.2.1: Paper Pulp

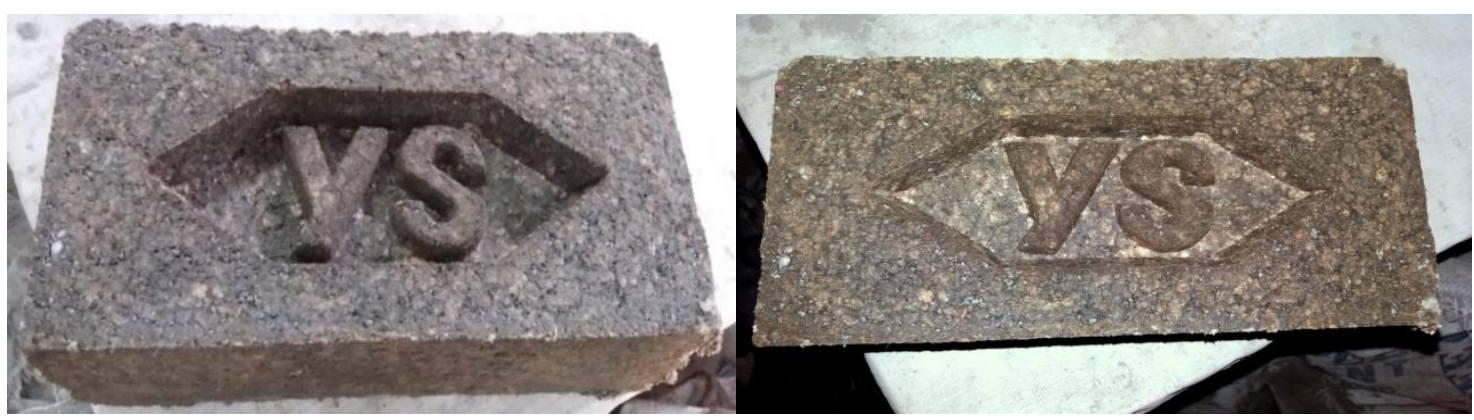

Figure 2.3.1: Papercrete bricks after casting

\section{Results and Discussion}

After casting the bricks they were analyzed for using as a brick. For this, various tests were conceded out to confirm the properties of bricks and the results of the test were analyzed by the existing and standard results. The following tests were carried out to check the strength of the brick.

\subsection{Compression Test}

This test was held out by Compression Testing Machine after the $14^{\text {th }}$ day from the date of casting papercrete brick. Papercrete bricks never fail catastrophically, it just compressed like squeezing rubber. Therefore great care must papercrete load should be applied up to half compression only.

The papercrete bricks are having elastic behavior and less brittleness, due to this the structure was not fully collapsed, when the papercrete brick fails at higher load. Only the outer faces cracked and peeled out.

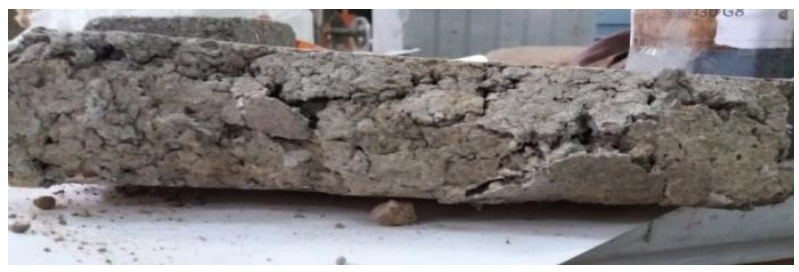

Figure 3.1.1: Brick after testing be considered while testing the papercrete brick because in

\subsection{Mixing}

Mixing was done after all the ingredients were ready. In this project, mixing was done manually.

A tried combination of cement: sand: paper sludge $(1: 1: 3)$ was used in this project. After the mixing, it should be put in the mould within 30 minutes and tamped with wooden tamper and the surface of the brick should be finished by shovel or wooden tamper. The casted papercrete bricks should be allowed for sun drying for 14 days. There is no such special care needed for curing of bricks because the paper used in bricks itself hold water for a long time. $\mathrm{N} / \mathrm{mm}^{2}$

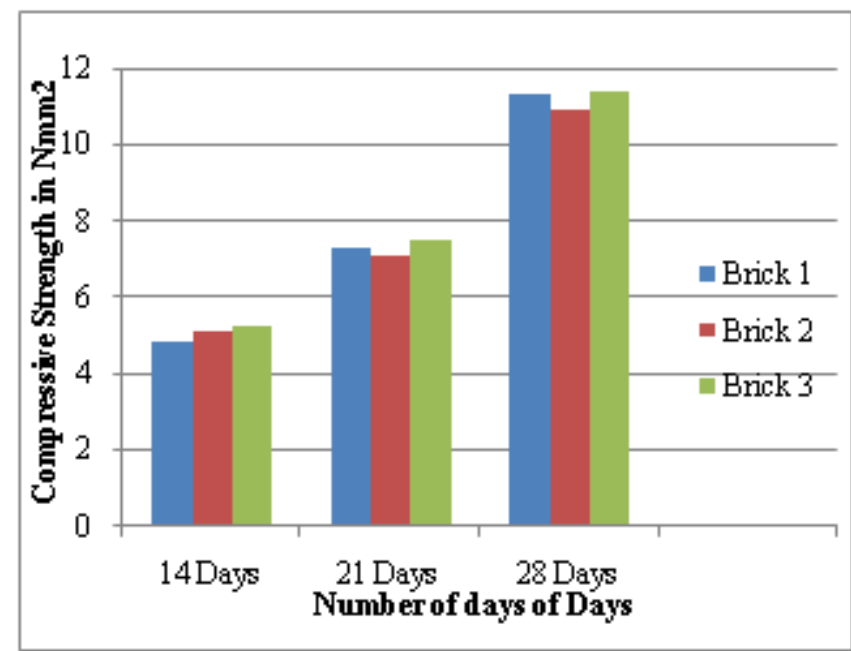

Figure 3.1.2: Variation in Compressive Strength of papercrete brick with no. of days

\subsection{Weight}

The ordinary conventional clay bricks weight varies from 3 $4 \mathrm{~kg}$ but the papercrete bricks weight varies from $1-2 \mathrm{~kg}$. The maximum weight is less than $2 \mathrm{~kg}$ only. All the bricks were weighed in a well conditioned electronic weighing machine. Sand based papercrete bricks are having weight $2 / 3^{\text {rd }}$ of the conventional clay brick only. 


\section{International Journal of Science and Research (IJSR) \\ ISSN (Online): 2319-7064 \\ Index Copernicus Value (2013): 6.14 | Impact Factor (2015): 6.391}

So these bricks are lightweight and thus helpful to reduce the total cost of construction due to areduction in total dead load of thestructure.

\begin{tabular}{|c|c|c|}
\hline No of days. & No. of Samples & Compressive Strength \\
\hline 14 Days & Sample 1 & $4.82 \mathrm{~N} / \mathrm{mm}^{2}$ \\
\cline { 2 - 3 } & Sample 2 & $5.13 \mathrm{~N} / \mathrm{mm}^{2}$ \\
\cline { 2 - 3 } & Sample 3 & $5.22 \mathrm{~N} / \mathrm{mm}^{2}$ \\
\hline \multirow{3}{*}{ 21 Days } & Sample 1 & $7.31 \mathrm{~N} / \mathrm{mm}^{2}$ \\
\cline { 2 - 3 } & Sample 2 & $7.11 \mathrm{~N} / \mathrm{mm}^{2}$ \\
\cline { 2 - 3 } & Sample 3 & $7.47 \mathrm{~N} / \mathrm{mm}^{2}$ \\
\hline \multirow{3}{*}{ 28 Days } & Sample 1 & $11.30 \mathrm{~N} / \mathrm{mm}^{2}$ \\
\cline { 2 - 3 } & Sample 2 & $10.90 \mathrm{~N} / \mathrm{mm}^{2}$ \\
\cline { 2 - 3 } & Sample 3 & $11.38 \mathrm{~N} / \mathrm{mm}^{2}$ \\
\hline
\end{tabular}

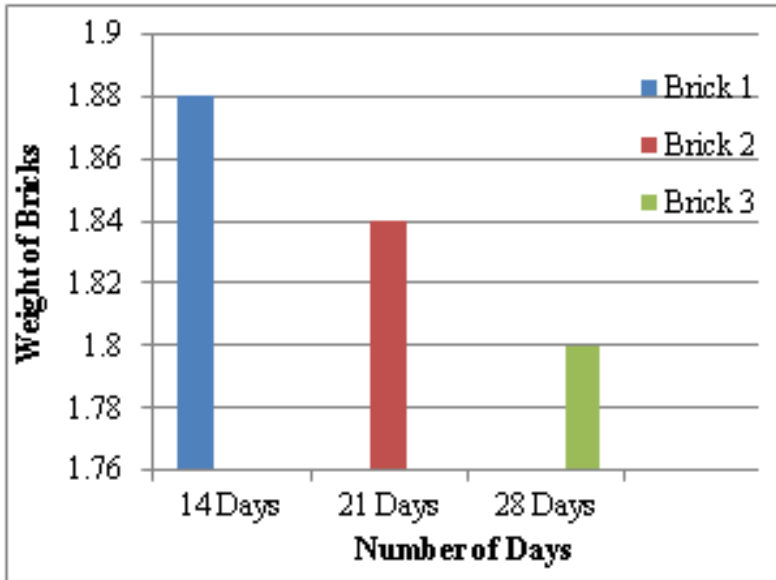

Fig. 3.2.1 Weight of papercrete bricks with no. of days

\subsection{Water Absorption Test}

Water absorption test is required to check whether the bricks are suitable for water logged areas or not. As per standards the bricks should not absorb water more than $20 \%$ of its original weight.

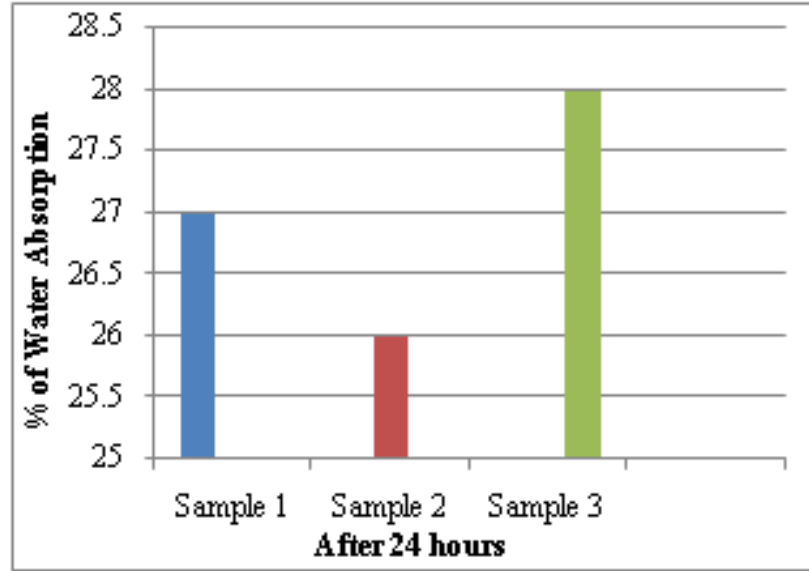

Figure 3.3.1: Water Absorption Test for Trial Mix

\subsection{Hardness Test}

In this test, a scratch was made on brick surfaces. While the scratch was made with the help of finger nail on the bricks, very light impression was left on the fibrous concrete brick surface. Hece, this test results that fibrous concrete bricks are sufficiently hard.

\subsection{Soundness Test}

In this test two bricks were taken and they were stuck with each other. The bricks were not broken and a clear ringing sound was produced. Hence the bricks are safe to use.

\subsection{Nailing}

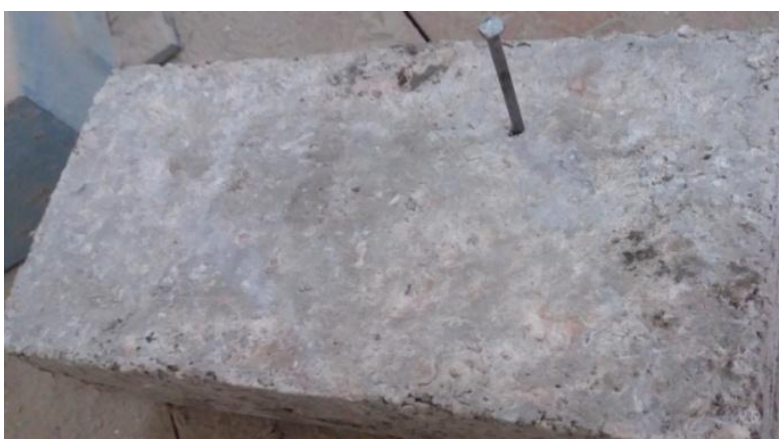

Figure 3.6.1: Nail in the brick

Fibrous concrete bricks are less hard as compared to conventional clay bricks. Therefore, this test was performed to find out whether these bricks can hold the nails or not. A nail was hammered in the brick and a screw was also screwed into the brick.

From this test it was observed that fibrous bricks can sufficiently hold the nail. Also screws worked well and holds a considerable weight.

\subsection{Cutting and Glue}

A lot of bricks are wasted on site during the process of cutting only. The labors could not able to cut the bricks exactly what they want. But papercrete bricks can be cut into exactly two parts by using conventional saw blades.

Many cut bricks are wasted in now a day. But the two fibrous concrete brick pieces can be hold together by putting a medium amount of glue on the bottom piece. Hence papercrete bricks could be emloyed in the application of calling for quick assembly by cutting the parts required to size in advance and letting the user simply glue them together.

\subsection{Fire Test}

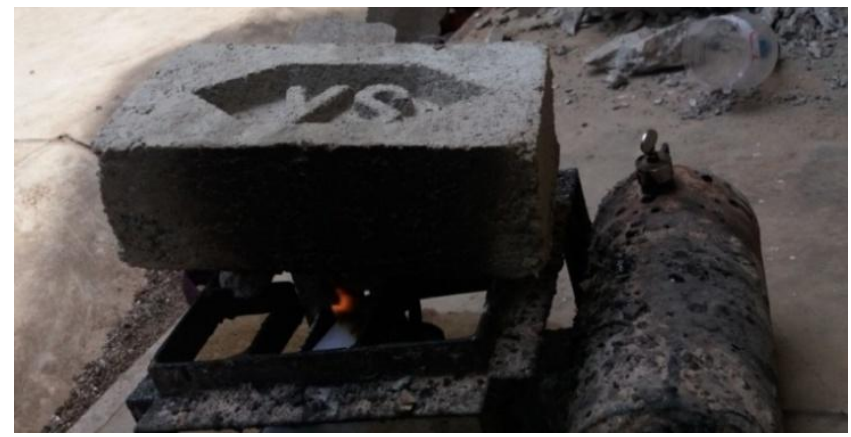

Figure 3.8.1: Fire test of papercrete brick

A brick, which is employed for construction should not flammable in an exposed fire, so this test was carried out for 


\section{International Journal of Science and Research (IJSR) \\ ISSN (Online): 2319-7064}

Index Copernicus Value (2013): 6.14 | Impact Factor (2015): 6.391

the bricks. This test was conceded out only for fibrous concrete bricks and not for padobe brick.

From the above test, it was observed that the fibrous concrete bricks did not burn with an open flame. They fumed like charcoal. But these brick would be reduced to ashes after burning several hours. If the interior plaster and exterior stucco is provided on the fibrous concrete bricks, the bricks won't burn. The only weak spot is inside the block, near electrical outlets, switches and other situations where wires gives through walls, into boxes etc. Properly wired places never cause a fire. If we apply the plaster without any hole or leakage on the bricks, it won't burn or fume inside because there will be a lack of oxygen for combustion.

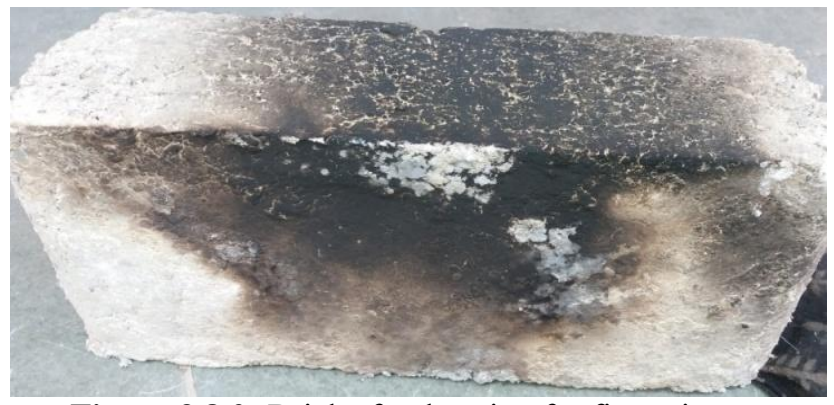

Figure 3.8.2: Brick after burning for five minutes

\section{Conclusion}

From the results obtained, the following conclusions were made:

- Considering the desirable compressive strength shown by the tested specimen, it is clear that papercrete have the ability to provide an ecofriendly, light weight concrete block with the use of less number of natural resources. Though the results obtained during compression test showed that papercrete bricks are acceptable for non load bearing walls only.

- As per research the bricks should not absorb water more than $20 \%$. The water absorption capacity of papercrete brick was found to be more than $20 \%$, which makes it not suitable for water logging and external walls. However, by providing a waterproof coating (Geobond or silicon based waterproofing) it can also be used as external wall.

- The weight of the papercrete brick was $1 / 3^{\text {rd }}$ to $2 / 5^{\text {th }}$ lesser than the conventional clay brick. Due to less weight of papercrete bricks, the total dead load of the building will be reduced.

- Due to lesser weight and more flexibility, these bricks are potentially ideal material for earthquacke prone regions.

- Papercrete has a high fire resistance,good sound absorbent, good thermal resistance with an $\mathrm{R}$ value between 2 to 3 per inch. In walls 12 to 16 inches thick, the long energy saving of papercrete will be a great advantage for the house owner and environmental.

- These bricks does not expand nor shrinks hence, sheets of glass or glass block can be fixed in and trimmed with papercrete.
- Since, papercrete brick mainly consists of waste material, it will reduce the landfills and pollution. Hence, the overall cost is very low as compared to conventional brick. It has been seen that by using papercrete bricks in a building construction, the total cost was reduced from $20 \%$ to $50 \%$.

\section{References}

[1] Agilan.V(2012)“Energy saving light weight bricks using waste newspaper" quest for advancement in Civil Engineering March 15, 2012

[2] Akinwumi, Olasunkanmi(2014)“'Structural Evaluation of Lightweight Concrete Produced Using Waste Newspaper and Office Paper "ISSN- 2224-5790 (PAPER), ISSN 225-0514 (ONLINE), Civil and environmental Research Volume No 6, No 7-2014.

[3] B J Fuller, AFafitis and J L Santamaria. (2006) "The Paper Alternative", ASCE Civil Engineering Vol. 75 No.5 pp. 72-77.

[4] Joo-Hong Chung, Byoung-Hoon Kim, Hyun-Ki-Choi and Chang-Sik Choi(2010) "Development of Papercrete due to Paper mixing ratio." SB10 Seoul: The International Conference on Sustainable Building Asia, February 2010.

[5] Lex Terry, (2006)“Papercrete Construction”- Building Environment and Thermal Envelope Council (BETEC) Symposium was held on $13^{\text {th }}$ to $16^{\text {th }}$ October 2006 at the Northen New Mexico Community College in EIRito.

[6] M.S Suganya(2012)"Lightweight bricks-made up of waste papers" International Journal of Computer \& Organization Trends-Volume 2, Special Issue 2, ISSN2249-2593, Number-2-April 2012.

[7] M.Scinduja, S.Nathiya(2014)“Innovative brick material using waste paper" International Journal for Research in Applied Science and Engineering Technology Special Issue-1,October 2014,ISSN: 2321-9653. 